\title{
MENINGKATKAN HASIL BELAJAR BAHASA INGGRIS DENGANMENGGUNAKAN MODEL PEMBELAJARAN COOPERATIVE TIPE STUDENT TEAMS-ACHIEVEMENTDIVISIONS (STAD) PADA MATERI TIMETABLE KELAS VIII SMP NEGERI 9 SOLOK SELATAN
}

\author{
HERIANSYAH. S
}

Guru Bahasa Inggris SMP Negeri 9 Solok Selatan, Solok Selatan

\begin{abstract}
Absract: The background of the research is the result of low student learning English, learning outcomes of students do not reach the KKM, this is caused by the learning model used is not in accordance with the material in the teaching and learning process that it makes them unintersted with the materials given, the ability of the students to answer the questions of items is still low, and we still find many students afraid and ashamed to ask some questions about the unknown materials given in the teaching and learning process. Some students often disturb other students and play when the materials are being given by the teacher. The purpose of research conducted to improve student learning outcomes of English using Cooperative Learning Model Type Student Teams Achievement Devisions (STAD). This type of research is the Classroom Action Research ( PTK ). The Subjects were VIII grade students of SMP Negeri 9 South Solok in the second semester of the school year 2019/2020. This research resulted in quantitative data in the form of data obtained from the results of tests conducted at each meeting in each cycle, and qualitatif data obtained from the observation sheet of students. Having conducted research for two cycles, each cycle two meetings, it was through the use of Cooperative Learning Model of Student Teams Achievement Divisions (STAD) Type, researchers succeeded in improving student learning outcomes characterized by an increase in classical learning completeness students. In the first cycle obtained classical learning completeness student by $68 \%$, then increased in the second cycle to 90\%, while improving student learning outcomes from the first cycle to the second cycle by $22 \%$. It can be concluded that the PTK is successfully improving student learning outcomes English Subtitles Time Table.
\end{abstract}

Keywords: Learning Outcomes, English, Cooperative Learning Model Type Student Teams Achievement Devisions (STAD), Time Table, Classroom Action Research.

\begin{abstract}
Abstrak: Latar belakang penelitian adalah hasil belajar siswa rendah, hasil belajar siswa tidak mencapai nilai KKM, hal ini disebabkan oleh model pembelajaran yang digunakan belum tepat sehingga siswa merasa bosan dan tidak tertarik dengan materi pembelajaran yang disampaikan, kemampuan siswa dalam menyelesaikan soal-soal masih sangat rendah, masih banyak siswa merasa takut dan malu bertanya tentang materi yang belum diketahui pada saat pembelajaran berlangsung, siswa sering mengganggu teman-temannya dan bermain-main pada saat pembelajaaraan berlangsung. Tujuan penelitian yang dilakukan untuk meningkatkan hasil belajar Bahasa Inggris siswa dengan menggunakan model pembelajaran Cooperative Tipe Student Teams Achievement Devisions (STAD). Jenis penelitian ini adalah Penelitian Tindakan Kelas (PTK).Subjek penelitian ini adalah siswa kelas VIII SMP Negeri 9 Solok Selatan pada semester II tahun pelajaran 2019/2020.Penelitian ini menghasilkan data kuantitatif yaitu berupa data yang diperoleh dari hasil tes yang dilakukan pada setiap pertemuan pada setiap siklus, dan data kualitatif yang diperoleh dari lembar


observasi siswa. Setelah dilaksanakan penelitian selama dua siklus, masing-masing siklus dua kali pertemuan, ternyata melalui pengunaan model pembelajaran Cooperative Tipe Student Teams Achievement Divisions (STAD), peneliti berhasil meningkatkan hasil belajar siswa yang ditandai oleh peningkatan ketuntasan belajar klasikal siswa. Pada siklus I didapatkan ketuntasan belajar klasikal siswa sebesar $68 \%$, kemudian meningkat pada siklus II menjadi 90\%, adapun peningkatan hasil belajar siswa dari siklus I ke siklus II sebesar 22\%.Sehingga dapat disimpulkan bahwa PTK ini berhasil meningkatkan hasil belajar Bahasa Inggris siswa materi TimeTable.

Kata Kunci: Hasil Belajar, Bahasa Inggris, Model Pembelajaran Cooperative Tipe Student Teams Achievement Devisions (STAD), TimeTable, Penelitian Tindakan Kelas.

\section{A. Pendahuluan}

Bahasa adalah alat komunikasi.Dia memiliki keragaman. Diantaranya adalah bahasa lisan (spoken language). Keterampilan berbicara ( speaking) tidak banyak mendapat perhatian pada pembelajaran bahasa inggris di SMP ( kurikulum bahasa Inggris. 1994 ) oleh karena itu, siswa SMP 90\% tidak mampu berbicara dalam bahasa Inggris. Dan juga keterampilan berbicara tidak diujikan dalam ulangan bersama Ujian Nasional. Ujian dititik beratkan pada keterampilan membaca (reading) dan tata bahasa (Structure / Grammar). Sementara kemampuan berbicara siswa sangat tidak kompeten, menyebabkan mereka enggan berkomunikasi dalam bahasa Inggris.Kondisi ini benarbenar terjadi di SMPN 9 Solok Selatan. Pembelajaran Keterampilan Berbicara (Speaking) disajikan sebatas penjelasan-penjelasan mengenai fungsi bahasa (Language Focus Function) dan ungkapan-ungkapan bahasa (Expression). Sebagai bahasa Inggris adalah merupakan alat komunikasi bahasa internasional.Bahasa asing pertama dan merupakan peranan penting dibidang diplomasi, perdagangan, juga dalam perolehan ilmu pengetahuan.

Agar komunikasi berjalan lancar perlu adanya interaktif antara guru dan siswa secara terorganisir, akan membuat siswa senang belajar. Salah satu alternative yang dapat ditempuh adalah penggunaan gambar (pictures) disamping menarik minat siswa juga menyenangkan (Enjoylable). Berdasarkan data yang diperoleh dari kegiatan belajar mengajar (KBM) di SMP Negeri 9 Solok Selatan pada mata pelajaran Bahasa Inggris, diketahui hasil belajar yang diperoleh siswa belum tercapai dengan maksimal.Hal ini dapat dilihat dari nilai tes siswa kelas VIII materi TimeTable masih dibawah Kriteria Ketuntasan Minimal (KKM) yang ditetapkan guru yaitu70.Untuk lebih jelasnya dapat dilihat pada tabel sebagai berikut:

\section{Tabel.1}

Nilai Tes Bahasa Inggris Siswa pada Materi TimeTable Kelas VIIISemester II Tahun Pelajaran 2019/2020 SMP Negeri 9 Solok Selatan

\begin{tabular}{|l|l|l|l|l|l|}
\hline No & Nama Siswa & KKM & $\begin{array}{l}\text { Nilai Tugas B. } \\
\text { nggris }\end{array}$ & Tuntas & \multicolumn{2}{l|}{ B. Tuntas } \\
\hline 1 & Amrizal J & 70 & 60 & & $\sqrt{ }$ \\
\hline 2 & Budiman & 70 & 45 & $\sqrt{ }$ & \\
\hline 3 & Citra Desri R Y & 70 & 70 & & $\sqrt{ }$ \\
\hline 4 & Desi Febriani & 70 & 55 & $\sqrt{ }$ & \\
\hline 5 & Deni Aguslia P & 70 & 80 & $\sqrt{ }$ & \\
\hline 6 & Ice Wahyuni P & 70 & 50 & $\sqrt{ }$ & \\
\hline 7 & Imron Rosadi & 70 & 70 & & \\
\hline
\end{tabular}




\begin{tabular}{|c|c|c|c|c|c|}
\hline 8 & Monica Nadila & 70 & 40 & & $\sqrt{ }$ \\
\hline 9 & Mairinal Putra & 70 & 55 & & $\sqrt{ }$ \\
\hline 10 & Rahma Yanti & 70 & 75 & $\sqrt{ }$ & \\
\hline 11 & Rahmat Gusti & 70 & 70 & $\sqrt{ }$ & \\
\hline 12 & Sonia Junita J & 70 & 50 & & $\sqrt{ }$ \\
\hline 13 & Siska Dewi Y & 70 & 70 & $\sqrt{ }$ & \\
\hline 14 & Sri Tuminah & 70 & 50 & & $\sqrt{ }$ \\
\hline 15 & Sintia Fransiska & 70 & 70 & $\sqrt{ }$ & \\
\hline 16 & Septria Wulan & 70 & 60 & & $\sqrt{ }$ \\
\hline 17 & Viddy Ignacia & 70 & 80 & $\sqrt{ }$ & \\
\hline 18 & Yulia Pisca C & 70 & 70 & $\sqrt{ }$ & \\
\hline 19 & Wahyu Prima $\mathrm{P}$ & 70 & 70 & $\sqrt{ }$ & \\
\hline \multicolumn{4}{|c|}{ Jumlah } & 10 & 9 \\
\hline \multicolumn{4}{|c|}{ Persentase } & $53 \%$ & $47 \%$ \\
\hline
\end{tabular}

Sumber: Buku Nilai Guru Mata pelajaran Bahasa Inggris

Melalui tabel di atas, dapat terlihat bahwa hasil belajar siswa masihrendah dan banyak yang belum mencapai Kriteria Ketuntasan Minimal (KKM)yaitu 70 pada pembelajaran Bahasa Inggris.Dari 19 siswa, yang tuntas hanya 10 orang dengan persentase $53 \%$ dan yang belum tuntas 9 orang dengan persentase $47 \%$. Oleh sebab itu untuk mencari solusi penyelesaian masalah tersebut maka peneliti mencoba menggunakan model pembelajaran Cooperative tipe Student Teams-Achievement Divisions (STAD) dalam pembelajaran diharapkan mampu mengatasi hasil belajar siswa serta mendapatkan hasil yang lebih baik dan sesuai dengan Kriteria Ketuntasan Minimal (KKM) yang ditetapkan yaitu 70, maka diperlukan model pembelajaran yang tepat.

\section{B. Metodologi Penelitian}

Berdasarkan masalah yang diteliti, maka jenis penelitian yang dilaksanakan ini adalah Penelitian Tindakan Kelas (PTK), yaitu penelitian yang merupakan serangkai tindakan-tindakan yang dilakukan secara bersiklus dan berkenan dengan perbaikan hasil pembelajaran pada suatu kelas.Suharsimi, dkk (2012:104) mengemukakan bahwa "PTK merupakan suatu penelitian yang akar permasalahaannya muncul di kelas, dan dirasakan oleh guru yang bersangkutan, penelitian tindakan kelas juga dapat menjembatani antara teori dan praktik. Penelitian Tindakan Kelas (PTK) dilaksanakan di kelas VIII SMP Negeri 9 Solok Selatan.Waktu penelitian dilaksanakan pada semester II tahun pelajaran 2019/2020 dalam 2 siklus.Pelitian ini yang di jadikan subjeknya adalah siswa kelas VIII SMP Negeri 9 Solok Selatan yang berjumlah 19 orang yang terdiri dari 9 orang laki-laki dan 10 orang perempuan. Penelitian Tindakan Kelas (PTK) terdiri dari 4 tahap yaitu, perencanaan, pelaksanaan, pengamatan, dan refleksi.Prosedur Penelitian Tindakan Kelas (PTK) dilakukan dalam 2 siklus, 2 kali pertemuan setiap siklusnya.Jika siklus I belum berhasil dilanjutkan kesiklus berikutnya. Data utama dalam penelitian ini adalah data kuantitatif dan data penunjang kualitatif, berikut pemaparan data penelitian: a) Data kuantitatif. Data kuantitatif adalah data yang berbentuk bilangan atau angka yang diperoleh dari hasil tes belajar siswa di setiap siklus; dan b) Data kualitatif. Data kualitatif adalah data yang tidak berbentuk angka atau berupa kalimat,datanya berupa aktivitas belajar siswa dalam penelitian yang dilaksanakan ini dikumpulkan dengan mengisi lembar observasi oleh teman sejawat ibu Yeli Marsih, S.Pd. 
InstrumenPenelitian yang dilaksanakan oleh peneliti ini mememiliki insterumen penelitian yang bertujuan untuk mengungkapkan fakta menjadi data yang dapat diklasifikasikan sebagai berikut: a) Tes, tes dilakukan untuk mengetahui dan mengukur seberapa besar pemahaman siswa terhadap materi yang sudah di pelajari, dan tes dilakukan pada setiap siklus.Tes yang peneliti gunakan berupa soal berbentuk objektif, b) Lembar observasi, Lembar observasi merupakan instrumen yang digunakan untuk memperoleh data kualitatif yang diisi oleh teman sejawat, dan c) Dokumentasi, dokumentasi yang peneliti gunakan adalah berupa foto-foto yang diambil pada waktu proses tindakan berlangsung, serta sebagai bukti sewaktu dalam penelitian yang dilakukan. Teknik Pengumpulan Datakuantitatif dikumpulkan dari hasil tes siswa yang dilakukan pada setiap siklus, dan data kualiatatif dikumpulkan dari lembar observasi siswa.

\section{Hasil dan Pembahasan}

Gambaran secara menyeluruh tentang tindakan yang dilakukan pada siklus I, nilai tes pada pertemuan I dan II berupa hasil belajar Bahasa Inggris siswa pada materi TimeTable pada siklus I, kemudian dibandingkan dengan Kriteria Ketuntasan Minimal (KKM) untuk melihat ketuntasan individual yang diperoleh. Setelah itu dicari persentase ketuntasan klasikalnya sesuai dengan rumus yang dikemukakan. Hasil belajar siklus I pertemuan I dapat dilihat pada tabel berikut ini :

Tabel.2 Hasil Tes Siswa Siklus I Pertemuan I

\begin{tabular}{|l|l|l|l|l|l|}
\hline No & Nama Siswa & KKM & Nilai & Tuntas & B. Tuntas \\
\hline 1 & Amrizal J & 70 & 80 & $\ddot{\mathrm{u}}$ & \\
\hline 2 & Budiman & 70 & 50 & & $\ddot{\mathrm{u}}$ \\
\hline 3 & Citra Desri R Y & 70 & 70 & $\ddot{\mathrm{u}}$ & \\
\hline 4 & Desi Febriani & 70 & 60 & & $\ddot{\mathrm{u}}$ \\
\hline 5 & Deni Aguslia P & 70 & 80 & $\ddot{\mathrm{u}}$ & \\
\hline 6 & Ice Wahyuni P & 70 & 70 & $\ddot{\mathrm{u}}$ & \\
\hline 7 & Imron Rosadi & 70 & 70 & $\ddot{\mathrm{u}}$ & \\
\hline 8 & Monica Nadila & 70 & 50 & & $\ddot{\mathrm{u}}$ \\
\hline 9 & Mairinal Putra & 70 & 80 & $\ddot{\mathrm{u}}$ & \\
\hline 10 & Rahma Yanti & 70 & 70 & $\ddot{\mathrm{u}}$ & \\
\hline 11 & Rahmat Gusti & 70 & 90 & $\ddot{\mathrm{u}}$ & \\
\hline 12 & Sonia Junita J & 70 & 90 & $\ddot{\mathrm{u}}$ & \\
\hline 13 & Siska Dewi Y & 70 & 70 & $\ddot{\mathrm{u}}$ & \\
\hline 14 & Sri Tuminah & 70 & 60 & & $\ddot{\mathrm{u}}$ \\
\hline 15 & Sintia Fransiska & 70 & 60 & & $\ddot{\mathrm{u}}$ \\
\hline 16 & Septria Wulan & 70 & 60 & & $\ddot{\mathrm{u}}$ \\
\hline 17 & Viddy Ignacia & 70 & 80 & $\ddot{\mathrm{u}}$ & \\
\hline 18 & Yulia Pisca C & 70 & 80 & $\ddot{\mathrm{u}}$ & \\
\hline 19 & Wahyu Prima P & 70 & 65 & & $\ddot{\mathrm{u}}$ \\
\hline Jumlah & & & 12 & 7 \\
\hline Persentase & & & $63 \%$ & $37 \%$ \\
\hline
\end{tabular}

Adapun hasil belajar siswa pada materi TimeTable pada siklus I pertemuan II dapat dilihat pada tabel berikut ini:

Tabel.3 Hasil Tes Siswa Siklus I Pertemuan II

\begin{tabular}{|l|l|l|l|l|l|}
\hline No & Nama Siswa & KKM & Nilai & Tuntas & B. Tuntas \\
\hline 1 & Amrizal J & 70 & 80 & $\ddot{u}$ & \\
\hline
\end{tabular}


Vol. 1 No.3 Desember 2019

Ensiklopedia Education Review

http://jurnal.ensiklopediaku.org

\begin{tabular}{|l|l|l|l|l|l|}
\hline 2 & Budiman & 70 & 60 & & $\ddot{\mathrm{u}}$ \\
\hline 3 & Citra Desri R Y & 70 & 80 & $\ddot{\mathrm{u}}$ & \\
\hline 4 & Desi Febriani & 70 & 60 & & $\ddot{\mathrm{u}}$ \\
\hline 5 & Deni Aguslia P & 70 & 80 & $\ddot{\mathrm{u}}$ & \\
\hline 6 & Ice Wahyuni P & 70 & 60 & & $\ddot{\mathrm{u}}$ \\
\hline 7 & Imron Rosadi & 70 & 80 & $\ddot{\mathrm{u}}$ & \\
\hline 8 & Monica Nadila & 70 & 60 & & $\ddot{\mathrm{u}}$ \\
\hline 9 & Mairinal Putra & 70 & 80 & $\ddot{\mathrm{u}}$ & \\
\hline 10 & Rahma Yanti & 70 & 80 & $\ddot{\mathrm{u}}$ & \\
\hline 11 & Rahmat Gusti & 70 & 80 & $\ddot{\mathrm{u}}$ & \\
\hline 12 & Sonia Junita J & 70 & 60 & & $\ddot{\mathrm{u}}$ \\
\hline 13 & Siska Dewi Y & 70 & 90 & $\ddot{\mathrm{u}}$ & \\
\hline 14 & Sri Tuminah & 70 & 80 & $\ddot{\mathrm{u}}$ & \\
\hline 15 & Sintia Fransiska & 70 & 60 & & $\ddot{\mathrm{u}}$ \\
\hline 16 & Septria Wulan & 70 & 90 & $\ddot{\mathrm{u}}$ & \\
\hline 17 & Viddy Ignacia & 70 & 80 & $\ddot{\mathrm{u}}$ & \\
\hline 18 & Yulia Pisca C & 70 & 90 & $\ddot{\mathrm{u}}$ & \\
\hline 19 & Wahyu Prima P & 70 & 70 & $\ddot{\mathrm{u}}$ & \\
\hline Jumlah & & & 13 & 6 \\
\hline Persentase & & & $68 \%$ & $32 \%$ \\
\hline
\end{tabular}

Nilai akhir hasil belajar siswa kelas VIII SMP Negeri 9 Solok Selatan pada siklus I ini disajikan pada tabel berikut ini:

Tabel.4

Nilai Akhir Hasil Belajar Siswa Siklus I Pertemuan I dan II

\begin{tabular}{|c|c|c|c|c|c|c|c|}
\hline \multirow{2}{*}{ No } & \multirow{2}{*}{ Nama Siswa } & \multirow{2}{*}{ KKM } & \multicolumn{2}{|c|}{$\begin{array}{l}\text { Nilai } \\
\text { Pertemuan }\end{array}$} & \multirow{2}{*}{$\begin{array}{l}\text { Nilai } \\
\text { Akhir }\end{array}$} & \multicolumn{2}{|c|}{ Ketuntasan Belajar } \\
\hline & & & I & II & & Tuntas & B. Tuntas \\
\hline 1 & Amrizal J & 70 & 80 & 80 & 80 & $\ddot{\mathrm{u}}$ & \\
\hline 2 & Budiman & 70 & 50 & 60 & 55 & & $\ddot{\mathrm{u}}$ \\
\hline 3 & Citra Desri R Y & 70 & 70 & 80 & 75 & $\ddot{\mathrm{u}}$ & \\
\hline 4 & Desi Febriani & 70 & 60 & 60 & 60 & & $\ddot{\mathrm{u}}$ \\
\hline 5 & Deni Aguslia P & 70 & 80 & 80 & 80 & $\ddot{\mathrm{u}}$ & \\
\hline 6 & Ice Wahyuni $\mathrm{P}$ & 70 & 70 & 60 & 65 & & $\ddot{\mathrm{u}}$ \\
\hline 7 & Imron Rosadi & 70 & 70 & 80 & 75 & $\ddot{\mathrm{u}}$ & \\
\hline 8 & Monica Nadila & 70 & 50 & 60 & 55 & & $\ddot{\mathrm{u}}$ \\
\hline 9 & Mairinal Putra & 70 & 80 & 80 & 80 & $\ddot{\mathrm{u}}$ & \\
\hline 10 & Rahma Yanti & 70 & 70 & 80 & 75 & $\ddot{\mathrm{u}}$ & \\
\hline 11 & Rahmat Gusti & 70 & 90 & 80 & 85 & $\ddot{\mathrm{u}}$ & \\
\hline 12 & Sonia Junita J & 70 & 90 & 60 & 75 & $\ddot{\mathrm{u}}$ & \\
\hline 13 & Siska Dewi Y & 70 & 70 & 90 & 80 & $\ddot{\mathrm{u}}$ & \\
\hline 14 & Sri Tuminah & 70 & 60 & 80 & 70 & $\ddot{\mathrm{u}}$ & \\
\hline 15 & Sintia Fransiska & 70 & 60 & 60 & 60 & & $\ddot{\mathrm{u}}$ \\
\hline 16 & Septria Wulan & 70 & 60 & 90 & 75 & $\ddot{\mathrm{u}}$ & \\
\hline 17 & Viddy Ignacia & 70 & 80 & 80 & 80 & $\ddot{\mathrm{u}}$ & \\
\hline 18 & Yulia Pisca C & 70 & 80 & 90 & 85 & $\ddot{\mathrm{u}}$ & \\
\hline 19 & Wahyu Prima $\mathrm{P}$ & 70 & 65 & 70 & 67,5 & & $\ddot{\mathrm{u}}$ \\
\hline \multicolumn{3}{|c|}{ Jumlah } & & & & 13 & 6 \\
\hline
\end{tabular}


Berdasarkan Tabel di atas, ketuntasan klasikal dari nilai akhir hasil belajar Bahasa Inggris siswa pada materi Time Table di kelas VIII SMP Negeri 9 Solok Selatan pada siklus I pertemuan I dan II dari 19 orang siswa, yang tuntas pada siklus I hanya 17 orang siswa dengan persentase $68 \%$ dan belum tuntas ada 11 orang siswa dengan persentase $32 \%$ yang nilainya belum mencapai Kriteria Ketuntasan Minimal (KKM) 70. Perbandingan ketuntasan belajar siswa pada siklus I antara yang tuntas dengan yang belum tuntas pada pembelajaran sosiologi materi nilai dan norma dengan menggunakan model pembelajaran Cooperative Tipe Student Teams Achievement Divisions (STAD) siklus I dapat dilihat pada gambar berikut ini:

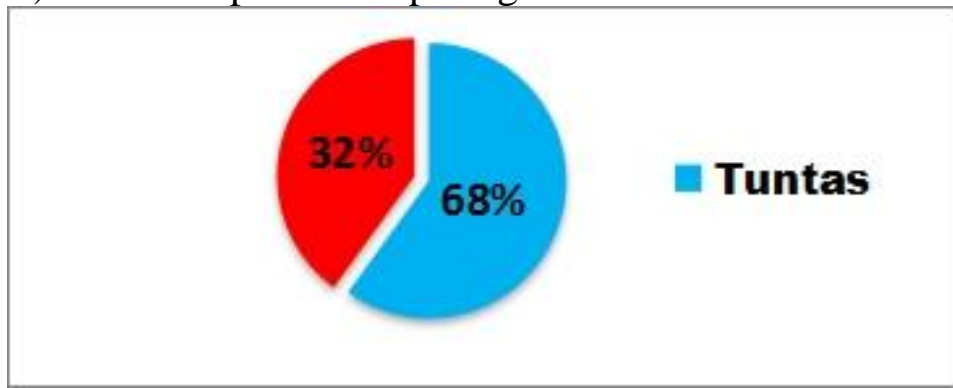

Gambar. 1 Perbandingan Siswa yang Tuntas dan Belum Tuntas Secara Klasikal pada Siklus I

Pada siklus II, kemudian dibandingkan dengan Kriteria Ketuntasan Minimal (KKM) untuk melihat ketuntasan individual yang diperoleh. Setelah itu dicari persentase ketuntasan klasikalnya sesuai dengan rumus yang dikemukakan pada bab III. Hasil belajar siklus II pertemuan I dapat dilihat pada tabel berikut ini :

Tabel.5

Hasil Tes Siswa Siklus II Pertemuan I

\begin{tabular}{|l|l|l|l|l|l|}
\hline No & Nama Siswa & KKM & Nilai & Tuntas & B. Tuntas \\
\hline 1 & Amrizal J & 70 & 80 & $\ddot{\mathrm{u}}$ & \\
\hline 2 & Budiman & 70 & 60 & & $\ddot{\mathrm{u}}$ \\
\hline 3 & Citra Desri R Y & 70 & 80 & $\ddot{\mathrm{u}}$ & \\
\hline 4 & Desi Febriani & 70 & 60 & & $\ddot{\mathrm{u}}$ \\
\hline 5 & Deni Aguslia P & 70 & 90 & $\ddot{\mathrm{u}}$ & \\
\hline 6 & Ice Wahyuni P & 70 & 60 & & $\ddot{\mathrm{u}}$ \\
\hline 7 & Imron Rosadi & 70 & 80 & $\ddot{\mathrm{u}}$ & \\
\hline 8 & Monica Nadila & 70 & 90 & $\ddot{\mathrm{u}}$ & \\
\hline 9 & Mairinal Putra & 70 & 90 & $\ddot{\mathrm{u}}$ & \\
\hline 10 & Rahma Yanti & 70 & 90 & $\ddot{\mathrm{u}}$ & \\
\hline 11 & Rahmat Gusti & 70 & 80 & $\ddot{\mathrm{u}}$ & \\
\hline 12 & Sonia Junita J & 70 & 70 & $\ddot{\mathrm{u}}$ & \\
\hline 13 & Siska Dewi Y & 70 & 90 & $\ddot{\mathrm{u}}$ & \\
\hline 14 & Sri Tuminah & 70 & 60 & & $\ddot{\mathrm{u}}$ \\
\hline 15 & Sintia Fransiska & 70 & 80 & $\ddot{\mathrm{u}}$ & \\
\hline 16 & Septria Wulan & 70 & 60 & & $\ddot{\mathrm{u}}$ \\
\hline 17 & Viddy Ignacia & 70 & 100 & $\ddot{\mathrm{u}}$ & \\
\hline 18 & Yulia Pisca C & 70 & 90 & $\ddot{\mathrm{u}}$ & \\
\hline 19 & Wahyu Prima P & 70 & 100 & $\ddot{\mathrm{u}}$ & \\
\hline Jumlah & & & 14 & 5 \\
\hline
\end{tabular}




\section{Persentase}

$74 \%$

$26 \%$

Adapun hasil belajar siswa pada materi nilai dan norma sosial pada siklus II pertemuan II dapat dilihat pada tabel berikut ini:

Tabel.6

Hasil Tes Siswa Siklus II Pertemuan II

\begin{tabular}{|l|l|l|l|l|l|}
\hline No & Nama Siswa & KKM & Nilai & Tuntas & B. Tuntas \\
\hline 1 & Amrizal J & 70 & 90 & $\ddot{\mathrm{u}}$ & \\
\hline 2 & Budiman & 70 & 80 & $\ddot{\mathrm{u}}$ & \\
\hline 3 & Citra Desri R Y & 70 & 90 & $\ddot{\mathrm{u}}$ & \\
\hline 4 & Desi Febriani & 70 & 80 & $\ddot{\mathrm{u}}$ & \\
\hline 5 & Deni Aguslia P & 70 & 100 & $\ddot{\mathrm{u}}$ & \\
\hline 6 & Ice Wahyuni P & 70 & 80 & $\ddot{\mathrm{u}}$ & \\
\hline 7 & Imron Rosadi & 70 & 100 & $\ddot{\mathrm{u}}$ & \\
\hline 8 & Monica Nadila & 70 & 90 & $\ddot{\mathrm{u}}$ & \\
\hline 9 & Mairinal Putra & 70 & 80 & $\ddot{\mathrm{u}}$ & \\
\hline 10 & Rahma Yanti & 70 & 100 & $\ddot{\mathrm{u}}$ & \\
\hline 11 & Rahmat Gusti & 70 & 90 & $\ddot{\mathrm{u}}$ & \\
\hline 12 & Sonia Junita J & 70 & 80 & $\ddot{\mathrm{u}}$ & \\
\hline 13 & Siska Dewi Y & 70 & 90 & $\ddot{\mathrm{u}}$ & \\
\hline 14 & Sri Tuminah & 70 & 60 & & $\ddot{\mathrm{u}}$ \\
\hline 15 & Sintia Fransiska & 70 & 90 & $\ddot{\mathrm{u}}$ & \\
\hline 16 & Septria Wulan & 70 & 60 & & $\ddot{\mathrm{u}}$ \\
\hline 17 & Viddy Ignacia & 70 & 100 & $\ddot{\mathrm{u}}$ & \\
\hline 18 & Yulia Pisca C & 70 & 100 & $\ddot{\mathrm{u}}$ & \\
\hline 19 & Wahyu Prima P & 70 & 100 & $\ddot{\mathrm{u}}$ & \\
\hline Jumlah & & & 17 & 2 \\
\hline Persentase & & & $90 \%$ & $10 \%$ \\
\hline
\end{tabular}

Nilai akhir hasil belajar siswa kelas VIII SMP Negeri 9 Solok Selatan pada siklus II ini disajikan pada tabel berikut ini:

Tabel.7

Nilai Akhir Hasil Belajar Siswa Siklus II Pertemuan I dan II

\begin{tabular}{|c|c|c|c|c|c|c|c|}
\hline \multirow{2}{*}{ No } & \multirow{2}{*}{ Nama Siswa } & \multirow{2}{*}{ KKM } & \multicolumn{2}{|c|}{$\begin{array}{l}\text { Nilai } \\
\text { Pertemuan }\end{array}$} & \multirow{2}{*}{$\begin{array}{l}\text { Nilai } \\
\text { Akhir }\end{array}$} & \multicolumn{2}{|c|}{ Ketuntasan Belajar } \\
\hline & & & I & II & & Tuntas & $\begin{array}{l}\text { Belum } \\
\text { Tuntas }\end{array}$ \\
\hline 1 & Amrizal J & 70 & 80 & 90 & 85 & $\ddot{\mathrm{u}}$ & \\
\hline 2 & Budiman & 70 & 60 & 80 & 70 & $\ddot{\mathrm{u}}$ & \\
\hline 3 & Citra Desri R Y & 70 & 80 & 90 & 85 & $\ddot{\mathrm{u}}$ & \\
\hline 4 & Desi Febriani & 70 & 60 & 80 & 70 & $\ddot{\mathrm{u}}$ & \\
\hline 5 & Deni Aguslia P & 70 & 90 & 100 & 95 & $\ddot{\mathrm{u}}$ & \\
\hline 6 & Ice Wahyuni $\mathrm{P}$ & 70 & 60 & 80 & 70 & $\ddot{\mathrm{u}}$ & \\
\hline 7 & Imron Rosadi & 70 & 80 & 100 & 90 & $\ddot{\mathrm{u}}$ & \\
\hline 8 & Monica Nadila & 70 & 90 & 90 & 90 & $\ddot{\mathrm{u}}$ & \\
\hline 9 & Mairinal Putra & 70 & 90 & 80 & 85 & $\ddot{\mathrm{u}}$ & \\
\hline 10 & Rahma Yanti & 70 & 90 & 100 & 95 & $\ddot{\mathrm{u}}$ & \\
\hline 11 & Rahmat Gusti & 70 & 80 & 90 & 85 & $\ddot{\mathrm{u}}$ & \\
\hline
\end{tabular}




\begin{tabular}{|l|l|l|l|l|l|l|l|}
\hline 12 & Sonia Junita J & 70 & 70 & 80 & 75 & $\ddot{\mathrm{u}}$ & \\
\hline 13 & Siska Dewi Y & 70 & 90 & 90 & 90 & $\ddot{\mathrm{u}}$ & \\
\hline 14 & Sri Tuminah & 70 & 60 & 60 & 60 & & $\ddot{\mathrm{u}}$ \\
\hline 15 & Sintia Fransiska & 70 & 80 & 90 & 85 & $\ddot{\mathrm{u}}$ & \\
\hline 16 & Septria Wulan & 70 & 60 & 60 & 60 & & $\ddot{\mathrm{u}}$ \\
\hline 17 & Viddy Ignacia & 70 & 100 & 100 & 100 & $\ddot{\mathrm{u}}$ & \\
\hline 18 & Yulia Pisca C & 70 & 90 & 100 & 95 & $\ddot{\mathrm{u}}$ & \\
\hline 19 & Wahyu Prima P & 70 & 100 & 100 & 100 & $\ddot{\mathrm{u}}$ & \\
\hline Jumlah & & & & & 17 & 2 \\
\hline Persentase & & & & $90 \%$ & $10 \%$ \\
\hline
\end{tabular}

Berdasarkan Tabel 7 di atas, ketuntasan klasikal dari nilai akhir hasil belajar Bahasa Inggris siswa pada materi TimeTable kelas VIII SMP Negeri 9 Solok Selatan pada siklus II pertemuan I dan II dari 19 orang siswa, yang tuntas pada siklus II ada 17 orang siswa dengan persentase $90 \%$ dan belum tuntas ada 2 orang siswa dengan persentase $10 \%$ yang nilainya belum mencapai Kriteria Ketuntasan Minimal (KKM) 70. Perbandingan ketuntasan belajar siswa pada siklus II antara yang tuntas dengan yang belum tuntas pada pembelajaran Bahasa Inggris materi TimeTable dengan menggunakan model pembelajaran Cooperative Tipe Student Teams Achievement Divisions (STAD) siklus II dapat dilihat pada gambar 4 berikut ini:

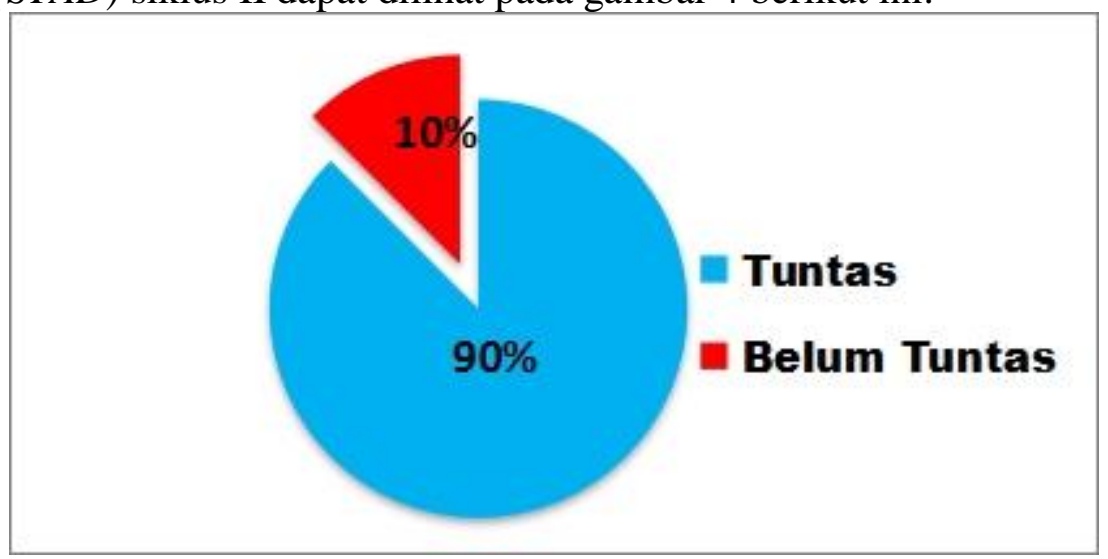

Gambar. 2

Perbandingan Siswa yang Tuntas dan Belum Tuntas Secara Klasikal pada Siklus II

Setelah dilaksanakan penelitian pada siklus I dan II, nilai hasil belajar Bahasa Inggris siswa materi TimeTable sudah mengalami peningkatan dibandingkan dengan siklus I.Hal ini dapat dilihat dari ketuntasan klasikal di siklus I sebesar 68\% siswa yang tuntas meningkat menjadi $90 \%$ siswa tuntas di siklus II,peningkatan tersebut dapat dilihat pada tabel 8 berikut ini:

Tabel.8

Peningkatan Hasil Belajar Bahasa Inggris siswa pada TimeTable dari siklus I ke Siklus II

\begin{tabular}{|c|c|c|c|c|c|c|}
\hline \multirow{3}{*}{ No } & \multirow{3}{*}{ Nama Siswa } & \multirow{2}{*}{\multicolumn{2}{|c|}{$\begin{array}{l}\text { Hasil Belajar } \\
\text { Bahasa Inggris }\end{array}$}} & \multicolumn{3}{|c|}{ Keterangan } \\
\hline & & & & \multirow[t]{2}{*}{$\begin{array}{l}\text { Meningka } \\
\text { t }\end{array}$} & \multirow[t]{2}{*}{$\begin{array}{l}\text { Teta } \\
\text { p }\end{array}$} & \multirow[t]{2}{*}{$\begin{array}{l}\text { Menuru } \\
\mathbf{n}\end{array}$} \\
\hline & & Siklus I & Siklus II & & & \\
\hline 1 & Amrizal J & 80 & 85 & $\ddot{\mathrm{u}}$ & & \\
\hline 2 & Budiman & 55 & 70 & $\ddot{\mathrm{u}}$ & & \\
\hline 3 & Citra Desri R Y & 75 & 85 & $\ddot{\mathrm{u}}$ & & \\
\hline
\end{tabular}

EISSN 2657-0289 Lembaga Penelitian dan Penerbitan Hasil Penelitian Ensiklopedia

PISSN 2657-0297 
Vol. 1 No.3 Desember 2019

Ensiklopedia Education Review

http://jurnal.ensiklopediaku.org

\begin{tabular}{|l|l|l|l|l|l|l|}
\hline 4 & Desi Febriani & 60 & 70 & $\ddot{\mathrm{u}}$ & & \\
\hline 5 & Deni Aguslia P & 80 & 95 & $\ddot{\mathrm{u}}$ & & \\
\hline 6 & Ice Wahyuni P & 65 & 70 & $\ddot{\mathrm{u}}$ & & \\
\hline 7 & Imron Rosadi & 75 & 90 & $\ddot{\mathrm{u}}$ & & \\
\hline 8 & Monica Nadila & 55 & 90 & $\ddot{\mathrm{u}}$ & & \\
\hline 9 & Mairinal Putra & 80 & 85 & $\ddot{\mathrm{u}}$ & & \\
\hline 10 & Rahma Yanti & 75 & 95 & $\ddot{\mathrm{u}}$ & & \\
\hline 11 & Rahmat Gusti & 85 & 85 & & $\ddot{\mathrm{u}}$ & \\
\hline 12 & Sonia Junita J & 75 & 75 & & $\ddot{\mathrm{u}}$ & \\
\hline 13 & Siska Dewi Y & 80 & 90 & $\ddot{\mathrm{u}}$ & & \\
\hline 14 & Sri Tuminah & 70 & 60 & & & $\ddot{\mathrm{u}}$ \\
\hline 15 & Sintia Fransiska & 60 & 85 & $\ddot{\mathrm{u}}$ & & \\
\hline 16 & Septria Wulan & 75 & 60 & & & $\ddot{\mathrm{u}}$ \\
\hline 17 & Viddy Ignacia & 80 & 100 & $\ddot{\mathrm{u}}$ & & \\
\hline 18 & Yulia Pisca C & 85 & 95 & $\ddot{\mathrm{u}}$ & & \\
\hline 19 & Wahyu Prima P & 67,5 & 100 & $\ddot{\mathrm{u}}$ & & \\
\hline Jumlah & & & 17 & & 2 \\
\hline \multicolumn{2}{|l|}{ Persentase } & Pada tabel 8 di & & $90 \%$ & & $10 \%$ \\
\hline
\end{tabular}

Pada tabel 8 di atas, dari hasil belajar pada siklus I dan IIterlihat bahwa17 orang siswa yang mengalami peningkatan hasil belajar pada mata pelajaran Bahasa Inggris materi TimeTable dengan menggunakan model pembelajaran CooperativeTipe Student Teams Achievement Divisions (STAD). Penggunaan model pembelajaran CooperativeTipe Student Teams Achievement Divisions (STAD) ini membawa dampak positif terhadap hasil belajar Bahasa Inggrissiswa kelas VIII SMP Negeri 9 Solok Selatan.

Selama pelaksanaan siklus I dan siklus II penelitian ini telah terjadi peningkatan hasil belajar, khususnya dalam ketuntasan klasikal siswa. Untuk lebih jelasnya disajikan dalam garafik berikut ini:

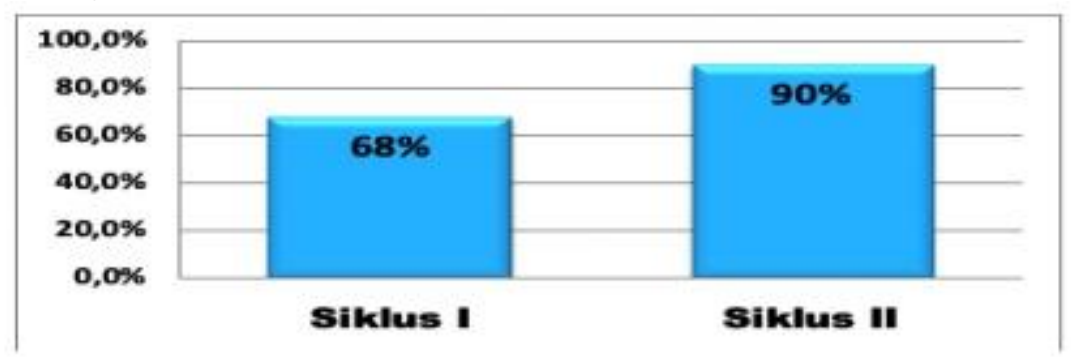

Gambar.3 Grafik Perbandingan Ketuntasan Siklus I dan II

Berdasarkan grafik di atas tergambar peningkatan hasil belajar siswa dari siklus I ke siklus II. Penggunaan model Pembelajaran Cooperative Tipe Student Teams Achievement Divisions (STAD) pembelajaran Bahasa Inggris pada materi TimeTable di kelas VIII SMP Negeri 9 Solok Selatan telah berhasil meningkatkan hasil belajar siswa. Hal ini membuktikan bahwa pelaksanaan Penelitian Tindakan Kelas (PTK) yang telah dilaksanakan telah berhasil meningkatkan hasil belajar siswa. Disamping itu, dari pelaksanaan proses pembelajaranjuga telah terjadi peningkatan aktivitas siswa dalam belajar sesuai dengan kegiatan yang dikemukakan dalam lembar observasi siswa. Dari pelaksanaan pembelajaran siklus I ke siklus II telah terjadi peningkatan aktivitas belajar siswa ke arah yang lebih baik. Oleh sebab itu penelitian dihentikan sampai siklus II ini. 


\section{Penutup}

Penggunaanmodel pembelajaran Cooperative Tipe Student Teams Achievement Divisions (STAD) dapat meningkatkan hasil belajar Bahasa Inggris siswa pada materi TimeTable. Pelaksanaan penelitian dari siklus I ke siklus II terdapat peningkatan hasil belajar untuk ketuntasan klasikal yaitu pada siklus I sebesar $68 \%$ dan meningkat di siklus II menjadi 90\%. Adapun peningkatan hasil belajar siswa dari siklus I ke siklus II sebesar 22\%. Model Pembelajaran Cooperative Tipe Student Teams Achievement Divisions (STAD) dapat melatih siswa agar dapat saling bekerja sama dalam kelompok belajar dan saling memotifasi antar anggota kelompok belajarnya.

\section{Daftar Pustaka}

Anas Sudijono. 2006. Pengantar Statistik Pendidikan. Jakarta: PT Raja GrafindoPersada.

Agustina.2012. Proses Belajar Mengajar Sekolah Menengah Atas.Padang:Universitas Negeri Padang, Kementrian Pendidikan dan Kebudayaaan.

Dimyanti dan Mudjiono. 2009. Belajar dan Pembelajaran. Jakarta: Rineka Cipta. Hamdani. 2011. Strategi Belajar Mengajar. Bandung: Pustaka Setia.

Imas Kurniasih dan Berlin Sani. 2014.Teknik dan Cara Mudah MembuatPenelitian Tindakan Kelas Untuk Pengembangan Profesi Guru.Penerbit: KataPena

Montero. 2011. Time table. Jakarta: Rineka Cipta

Monica. 2011. Gemar berbahasa Inggris. Jakarta

Rusman. 2014. Model-model Pembelajaran Mengembangkan ProfesionalismeGuru. Jakarta: PT Raja Grafindo Persada.

Suharsimi, dkk. 2012. Penelitian Tindakan Kelas. Jakarta: PT Bumi Aksara.

Slavin, R. E. 2008.Cooperative Learning: Teori, Riset dan Praktik. Bandung:Nusa Media Ujungberung.

Sapriya. 2011. Pendidikan IPS. Bandung: PT Remaja Rosdakarya.

Sri Anitah W, dkk. 2010. Strategi Pembelajaran di SMA.Jakarta: UniversitasTerbuka.

Taufina dan Muhammadi. 2011. Mozaik Pembalajaran Inovatif. Padang:SukaBina Prees.

Thobroni. 2015. Belajar \& Pembelajaran Teori dan Praktik.Yogyakarta: ArRuzzMedia.

Wahab. 2008. Konsep Dasar IPS. Jakarta: Universitas Terbuka.

Wikipedia. 2011. Pengertian Bahasa ingris.

Zainal Arifin. 2012. Evaluasi Pembelajaran. Jakarta: Direktorat JendralPendidikan Islam Kementrian Agama RI. 